\title{
Decolonizing contemporary art exhibitions
}

\section{Okwui Enwezor (1963-2019), the turning point of curatorship}

\section{Elvan Zabunyan}

In the twenty-first century, the history of exhibitions has become a crucial field for those interested in contemporary commitments to present renewed visions of the world. These visions of the world are reinvented because we choose to consider them from the point of view of history, a history that would engage in the 'globality' conceptualized by Édouard Glissant (1997). These commitments are clearly dealing with global knowledges, European colonial empires, postcolonial critical studies, alternative art practices, gender and racial concerns, and the deconstruction of hegemonic centres and peripheral realms. As one of the most innovative curators of the last two decades, Okwui Enwezor (1963-2019) managed to restructure conceptions of history and culture, and question from the inside the effect that 'alternating currents' have on a globalized art world. In choosing to free up boundaries, he produced shifts between cultural and artistic identities. As a curator, Enwezor participated in the upheavals of all predominant Eurocentric paradigms through institutions offering contemporary artists a pluriverse platform to present competing interpretations of the past. By choosing to decolonize exhibition modalities, while maintaining historical continuity with the models of major international contemporary art exhibitions, he succeeded in reframing colonial history through the practices of artists (Knudsen 2018).

The last major group exhibition organized by Okwui Enwezor while he was still director of Haus der Kunst in Munich (he was the museum's director from 2011 to 2018) was entitled Postwar: Art Between the Pacific and the Atlantic, 1945-1965. It was the first time in the history of exhibitions that this crucial post-war period had been considered from a global perspective (Enwezor et al. 2016). As he explained in a lecture in Paris in 2016, it was no longer a question of making vertical art history based on the main artistic centres of the time (Paris and New York, in particular) but a horizontal history of art (Enwezor 2016). What was important to him was to propose a history of the post-war era not by focusing on Europe and the United States but by highlighting the numerous other scenes around the world in Asia, Africa, the Middle East, and Latin America. The project was not about rewriting art history, but rather about broadening the boundaries of our 
understanding of art and carefully examining the work of the artists: 'The goal of the exhibition was to look globally at what the artists make where and with what' (Enwezor 2016). The exhibition allowed him to examine the narratives he called 'missing'. The note available on the Haus der Kunst website sums up Okwui Enwezor's intentions perfectly:

In eight dramatic chapters, the exhibition guides visitors through the 20 years following the Second World War, demonstrating how artists coped with, and responded to, the traumas of the Holocaust, Hiroshima and Nagasaki; how the two political blocs of the Cold War exploited the arts and created an opposition between realism and abstraction, and how displacement and migration produced new cosmopolitan contexts across the world. The post-war period also marked the end of European colonial systems; the rise of nation-building, decolonisation and liberation movements; partition of countries in Europe, Asia and the Middle East; as well as the Civil Rights movement in the United States. These changes unleashed an incredible energy visible in the art of the time. New technologies began to pour into everyday life; the space age fascinated artists as well as the masses, opening up a completely new and dynamic field of artistic consideration. ${ }^{1}$

Taking into account all the political, scientific, cultural, and artistic dynamics in order to think about this period is a method Enwezor applied to all his curatorial projects. It is inconceivable for him to detach artistic creation from its production context. Looking at this global history from the point of view of contemporary art also allowed him to integrate into his thinking historical questions and events that have been neglected by mainstream history and that have not been sufficiently considered to be connected. Their correlation, however, reinforces the collective nature of their agency.

Okwui Enwezor thus insists on the correspondences: the civil rights movement in the United States was inspired by decolonization movements in different parts of the world; as is well known, the emancipation models conceived by Gandhi were taken up by Martin Luther King. In this sense, it is necessary, according to Enwezor, to study 'the way art and artists confronted the disillusion of colonial empires' (Enwezor 2016). When he referred to events such as the September 1961 Belgrade conference of the Non-Aligned or the First Solidarity Conference of Peoples of Asia, Africa, Latin America, the Tricontinental Conference held in Havana on 3 January 1966 and decided to include them in his Postwar exhibition, he was clearly evoking historical moments following the Bandung Conference of 1955 that initiated the NonAligned Movement in the midst of the Cold War. This was a major event whose analysis is also at the heart of research initiated by the South American School of Decolonial Thinkers which works on 'epistemologies of the South' (De Sousa Santos 2014). Their reflections today occupy an increasingly prominent place in the context of contemporary art (Allain-Bonilla et al. 2020). 
The Tricontinental was a conference of revolutionary movements from Africa, Asia, and Latin America (Primera Conferencia de Solidaridad de Los Pueblos de Africa, Asia, America Latina), which emerged from two important dynamics both linked to the anti-colonial movements (Barcia 2009). First, the dynamic of the Non-Aligned Movement (NAM), created in 1961, which included certain regimes with a more conciliatory attitude towards the colonial empires. Second, the dynamic that was constituted outside of the NAM with the creation of the Afro-Asian People's Solidarity Organisation (AAPSO) in 1957, which concerned other movements in the context of still unfinished anti-colonial wars and was of a more radical nature. The NAM and AAPSO platforms often collaborated and made possible the production of the cultural meeting that took place in Havana with the Tricontinental (Mahler 2018). These moments when the modalities of anti-colonial struggles are collectively discussed allow us to question the forms of artistic and critical expression created at the same time. With his exhibition, by integrating these events into the 1945-1965 timeline in the same way as known and recognized events in the Western world, Okwui Enwezor analysed how these struggles and commitments influence artistic production, how artists themselves participate in the elaboration of concepts that extend the field of cultural production, and how artistic circulations are developed. By choosing to study the post-war era and, in particular, the crucial tipping point of decolonization in the 1960s, he opened up new horizons for the interpretation of world art history. He thus confirms that this interpretation did not just come into being in the 1990s, as is often stated, but already existed 30 years earlier.

However, the 1990s enabled the theorization of concepts that marked an indisputable turning point in art epistemology. The contemporary art world was then in the midst of a metamorphosis, seeking, in the continuity of the effects produced by certain large-scale exhibitions like the 1986 Havana Biennial, 1989 Magiciens de la terre, and the 1993 Whitney Biennial, to understand the importance of a reflection based on the issues of difference and marginalization. In Havana and in Paris, for the first time, artists from the Asian and African continents were exhibited together at an international event; in New York, works from African-American artists, who until then had little institutional visibility, were shown. Cultural and postcolonial studies were then convened like a new critical apparatus, allowing art history to decompartmentalize itself. ${ }^{2}$ Based on a contemporary reading of the consequences of colonization and decolonization, and of immigration and exile, intellectuals and artists questioned the forms of inclusion and exclusion operating in the field of social and artistic practices. They thereby used the tools of decolonization to deconstruct their own field. Through their production, they committed to examining racial, social, or gendered problematics. Within the exhibitions themselves, moving, fluid, syncretic, artistic temporalities and spatialities gave new life to the modalities of mobility. The theoretical concepts were therefore tied to the work of the artists. This transformed 
landscape of contemporary art has had an impact on the way works are read by art historians and curators, who are consequently opening up to transversal methodologies and artistic pluriversality.

\section{The exhibition as a medium to deconstruct the dominant history}

Because it welcomes and connects in the same space works produced by artists from all around the world, the 'exhibition' as a medium, particularly when it involves large-scale group shows such as biennales, is becoming an increasingly important field of study and a true space of hospitality. The coexistence of pictorial, sculptural, filmic, photographic and performative forms, their meeting, their dialogue, their assembly, give rise to the intermingling of thousands of fragments, as many as the artistic proposals conceived in connection with the creative contexts located on the five continents. These moments of shift and fusion between art and politics, between art and cultural differences, between art and the history of the past, are those that allow the development of another history; a history inherent in artistic and intellectual universes that articulate with each other as a means of promoting vanishing lines that undo authoritarian and conservative points of view. The latter formats the modalities of creation according to criteria that claim to be universal, but which are above all formalized and inscribed in an academic tradition that does not include pluriversity. Okwui Enwezor insisted on the deconstruction of the European canon of fine arts that gave rise to modernism. According to him, it was necessary to emphasize that this modernism does not have a dominant status as its sole privilege.

In Okwui Enwezor's method, there is always the desire to think about the exhibition in the form of juxtapositions, as two boundaries that touch each other and highlight differences and affinities. The works that meet in a space are there to establish entanglements of meanings, forms, historical and artistic narratives. For the curator and director of the museum, the relationship to a revisited chronology of history is at the centre of a reflection based on a geopolitical and social as well as poetic and aesthetic analysis of artistic production. The exhibition is the place of all convergences, where encounters as well as dialogue between artists and intellectuals from all over the world are possible. The exhibition provides an opportunity to reshuffle the diplomatic cards, to change institutional perspectives and to modify the viewpoints standardized by European hegemony. 'All my work as a curator has been devoted to implicate different territories of practice in the exhibition', Enwezor explains (Enwezor 2016). These different territories and the distinct but complementary fields of specialization are also related to his own intellectual biography.

Born in October 1963 in Calabar, Nigeria, Okwui Enwezor arrived in New York in 1983 to study. He graduated in political science at the Jersey City State College. But he was also a poet, and it was through writing that he 
began to reflect on the context of contemporary art and noted the glaring absence of African artistic practices in the public and private institutional framework, whether in galleries or museums. In 1994, to compensate for this invisibilization, he founded the journal Nka: Journal of Contemporary African Art with Salah Hassan. Published by the Africana Studies and Research Center (ASRC) at Cornell University, it chose to present African artists or artists of the 'African Diaspora', thus reflecting a production that focuses on a long history that integrates the legacy of slavery in the Americas (North, South, Caribbean), but also of colonization and subsequent migrations.

Taking into account his own experience of migration between the African continent and North America, he analysed the chronological milestones that mark the historical moments that need to be reconsidered from off-centre perspectives. He applied these questions specifically to cultural displacements beginning with his first major curatorial project, the second Johannesburg Biennial, organized in 1997 in a South Africa just emerging from apartheid (Becker and Enwezor 1998). Enwezor decided to deviate from the sense of national belonging and decided to curate a project where the usual definitions of an art that would resemble a national identity are voluntarily blurred. Traditionally, a biennial brings together, by national section, the work of artists from different countries. Enwezor chose instead to invite six co-collaborators of different origins (Gerardo Mosquera from Cuba, Hou Hanrou from China living in Paris, Yu Yeon Kim living in Seoul and New York, Octavio Zaya from Spain living in New York, Kellie Jones an AfricanAmerican living in New York, and Collin Richards from South Africa). They would in turn select artists whose works were part of a reflection on the notion of borders, which had to be overcome in order to avoid national recognition. The numerous geographical displacements, a consequence of colonization and/or immigration, were taken into account as an essential parameter: almost all the curators were living outside their country of origin or shared their time between two different cities, at least one of which was integrated into the Western world. Whether they came from Cuba, China, Korea, Spain, the United States, or South Africa, all of them explored the limits of nationalism critically in all its forms. Beyond the idea of nation, the idea of community was thought of as fluid, open, appealing to unprecedented temporalities. This mobility, both physical and artistic, was also to be read in light of the African diaspora to which Okwui Enwezor belonged, the subjective experience motivating in some way the intellectual construction. Curating an exhibition in relation to a historical context that sheds light on the present and the urgency of analysing this context through art was always the starting point of his thinking.

\section{The short century}

In Europe, the exhibition that propelled Okwui Enwezor to the peak of celebrity as a curator was The Short Century: Independence and Liberation 
Movements in Africa 1945-1994 held between February and April 2001 at the Museum Villa Stuck in Munich. As Julia Friedel recalls, more than 15 years later, 'the first German blockbuster exhibition of contemporary art from the African continent was born' (Friedel 2018). With this large-scale project, Enwezor chose to make Africa the primary laboratory of his curatorial expertise by insisting on the historical nature of the independence and liberation movements of a continent that was decimated by colonization. Nevertheless, this exhibition concept, articulating history, culture, philosophy, economics, and politics, served as a framework for almost every other exhibition he organized thereafter. This concept based on pluri- and transdisciplinarity allows him to make Africa radiate on a world scale without it being the exclusive centre of its preoccupation, or being thought of as a theme defined according to a cultural area. Indeed, Africa as it is presented in The Short Century is at the heart of global transfers, its history irrigates that of the world, a world that has coveted it for its resources, that has exploited it to leave it drained but that reveals itself through an artistic potential that has been unknown and neglected, a potential that is born from the ashes of colonization with all its symbolic power (Dawson 2003). It is thus the African modernity at the time of decolonization that he chose to show with this project, with this pivotal date of 1945 as a starting point: 'Decolonization, and its attendant ideological and philosophical contestation of Western imperialism, does ... remain one of the most significant events of the twentieth century ...', he wrote in the introduction to the exhibition catalogue (Enwezor 2001, 10).

In an interview with Carol Becker, Okwui Enwezor spoke at length about the genesis of the project, both the exhibition and the book, as well as the foundations of his thinking:

There has been a range of historical shows that looked at the intersection between political and ideological forces and the ways in which artists and intellectuals responded. However for a continent that is really an unknown quantity, one that not many people have been in contact with in any substantial way, it presents a very different challenge in terms of the kind of material that you can put into an exhibition. How do people apprehend, distill and interpret the range of materials that may not yield their full meaning on a visual platform alone? Working with both primary sources and interpretations of these sources was crucial. Chronologically, the exhibition ends in 1994 to make that point of transition and the beginning of something else. More important it has two book-ends. One is 1884 to 1945. In 1884, the year-long Berlin conference began; it was the source of the Berlin Congo Act, which resulted in the partition of Africa among the European powers. The show does not really touch the process of colonization. But it touches the results of course. The second book-end is the post-apartheid period, which for me really represents the exhibition: the continuous meditation by 
intellectuals and artists of the subject of decolonization: the agoras of decolonization, the discontinuities of decolonization, and the problematics of the heritage of decolonization.

(Becker and Enwezor 2002, 14)

For Enwezor, the chronological milestones, 1945-1994, he chose for the exhibition are crucial because they refer to the events that mark the beginning and end of African struggles for independence. October 1945 is indeed the date of the 5th Pan-African Congress held in Manchester, a major event since the decisions taken there, a few months after the war, opened up concrete prospects for African independence. Other events that The Short Century recounts include the Négritude movement, Pan-Africanism, Pan-Arabism, but also the wars of independence of Algeria (1954-1962), Mozambique (1964-1974), and Angola (1961-1974). The date 1994 that concludes the chronology is the end of apartheid in South Africa with the first multiracial legislative elections and Nelson Mandela's election as president on 10 May 1994.

The exhibition presented 60 works by more than 40 artists. Some, such as Alexander Skundar Boghossian, born in Ethiopia in 1937, of African and Armenian origin, spent a large part of his life in the United States (he died in 2003 in Washington, DC). His painting is based on the notion of travel, of transition from one culture to another, from the permanence of this 'double consciousness' studied by W. E. B. Du Bois as early as 1903 in The Souls of Black Folk; a 'double consciousness' that Okwui Enwezor made his own, like many intellectuals and artists who live between two cultures and who navigate in this in-between space granted by interculturality (Ifversen 2018). The work of Alexander Skundar Boghossian was also exhibited by Okwui Enwezor in Postwar. The curator often worked very faithfully with several artists as if they represented for him both aesthetic and political anchors that allowed him to draw this essential historical thread that constantly connects the past to the present. ${ }^{3}$ In the spatial arrangement of the works, pictorial and sculptural forms are juxtaposed with filmic forms, visual and textual archives. The status of each exhibited element is considered in relation to the others. Thus, in one of the exhibition rooms, the film Les Maîtres fous (1954) by the French anthropologist Jean Rouch (1917-2004) stands side by side with the bronze sculpture Killed Horse (1962) by the South African artist Sydney Kumalo (1935-1988). The wall text accompanying Rouch's film explains: 'This film was banned for 20 years by the colonial powers because of its depiction of the Senegalese ritual of imitation'. The work exists in the exhibition as a visual testimony of rituals that critically mark colonization. The mention of the censorship it has undergone belongs to its history as much as to that of a long history of colonization and decolonization.

It is in the hanging of the works and the installation of the various showcases in the exhibition space that Okwui Enwezor, like any curator, creates a spatial language where the dialogues produce meaning beyond a simple formal approach. In one of the rooms devoted to architecture, the 
representations of the Medina, the Kasbah, the Native Quarter, the Township, and the Settler's city are all examples of spatial configurations confronting colonial power and social and economic imbalances. As Enwezor recalls in his conversation with Becker:

The notion of the West is a fiction. The West does not exist insofar as it represents a body of knowledge to which we are supplements...The artists I've known and have worked with bringing us back to postcolonial in the widest and deepest sense of the word, that is, as the heritage of all of us, because the postcolonial is this place of rupture. We can no longer attempt to articulate the postcolonial as the elsewhere of the West, when in fact, it is the West. It wasn't only Africa that was decolonized; the end of empire was also a process of decolonization.

(Becker and Enwezor 2002, 25)

Making the West a fiction and the postcolonial experience a breaking point gives new breadth to the fields of theoretical and artistic knowledge (Chakrabarty 2000; El-Tayeb 2011; Hassan and Dadi 2001; Sakai 2001). The rupture is only a rupture because it creates new ways of thinking about the history of art and the history of exhibitions. Enwezor gives an adequate response to these cultural interrelationships by confirming that the curator has the responsibility to orient critical thinking by using art as a support:

The curator who endeavours to leave the institutional area of history and the canon has to risk a little bit. That is to curate within culture is to see art in a totality that is not simply bounded by art history. It is there that we begin to make room for new forms of knowledge, new possibilities of articulating different types of intelligence that are unruly and cannot be disciplined by [the] academic world. That means that often the curator needs to be experimental.

(Becker and Enwezor 2002, 26)

For Okwui Enwezor, curating exhibitions was a way of confronting history, of being a reflection of it. When he was entrusted with the artistic direction of the 11th edition of the Documenta, this experimental form that he gave to the making of an exhibition was forcefully revealed.

\section{Documenta I I}

When The Short Century exhibition opened in Munich on 15 February 2001, the Documenta project curated by Enwezor was ongoing. While the opening was an important moment for the art of the African continent, the appointment of the first 'non-European', and African, curator at the head of a prestigious international contemporary art event was a decisive turning point for art history. The Documenta in Kassel, a monumental exhibition, which, every 
five years proposes the discovery of the work of guest artists from cross perspectives, is an exemplary case study for understanding the cultural, diplomatic, and economic mechanisms that have made up the artistic landscape since the second half of the twentieth century, which find expression through the intertwining that is made possible by the interculturality of artists and their production. Created in 1955 in a Germany split between East and West, bearing the fracture of the Cold War, Documenta has since followed a path tracing alternative pathways for contemporary art.

The year 1955 was also the date of the Bandung conference, already mentioned above, where, in the midst of decolonization, countries that chose not to belong to either bloc positioned themselves as 'non-aligned' and appropriated the notion of the Third World as an Afro-Asian emancipatory force. In the various editions of Documenta, from its creation to the present day, contemporary artistic proposals have been based on discursive and aesthetic forms that are most often progressive. At the same time, however, they exist according to the standards imposed by the art market and art tourism, which sometimes deactivate their initial potential. Okwui Enwezor's Documental1 allowed for an unparalleled paradigmatic shift since it was the first global attempt to literally decolonize art history and artistic practices. In an interview with Rex Butler entitled 'Curating the World', published in 2008 in the Australian and New Zealand Journal of Art, Enwezor points out: 'I wanted to begin with the idea that the world rather than Kassel was the central animating factor, and that Kassel was only one platform' (Butler and Enwezor 2008, 18 ), before adding a little further, as a reminder:

The art world is shifting. Who could have imagined all that has changed from even ten years ago? Many things are different. Without the 1990s there would not be a global art system. No one thinks Paris or New York is the centre of art anymore (20).

To confirm the paradigm shift of the exhibition itself, Enwezor, with his team of co-curators (Carlos Basualdo, Susanne Ghez, Sarat Maharaj, Ute MetaBauer, Octavio Zaya, and Mark Nash), chose to break the event into five platforms, each held in a different city on the European (Vienna, Berlin), Asian (New Delhi), African (Lagos), and American (Saint Lucia) continents, with the fifth platform being the exhibition in Kassel. These platforms and the different places chosen were symbolically arranged according to the philosophical idea of archipelagos enunciated by Édouard Glissant, whose thinking illuminated the platform Créolité and Creolization in Saint Lucia. The five platforms were held staggered between March 2001 and September 2002.

In order to understand the theoretical genesis of Documental1, it is important to consider the year 1997, which marked not only the opening of Documenta $X$, under the artistic direction of Catherine David, but also the second Johannesburg Biennial mentioned above. By considering art history, philosophy, sociology, economics, political science, law, ethnology, and 
anthropology as critical tools, the 1997 Documenta was a vehicle for a theoretical charge that at the same time opened the way to new reflections on art and its process. During the 100 days of the event, Catherine David brought together a conference of artists and intellectuals. Major personalities were invited, notably tutelary figures of postcolonial studies like Edward Said and Gayatri C. Spivak. Valentin-Yves Mudimbe, Abderrahmane Sissako, Raoul Peck (whose 1991 film Lumumba, The Death of the Prophet was presented in the exhibition), Ariella Azoulay, Carlos Basualdo, Geeta Kapur, Wole Soyinka, Okwui Enwezor, Étienne Balibar came to speak at this monumental exhibition designed according to an urban itinerary that explored the movements of artists. In the voluminous Politics/Poetics catalogue, the chronology begins in 1945, and extracts from literary, philosophical, and theoretical texts of Aimé Césaire, Frantz Fanon, Édouard Glissant, Gilles Deleuze and Félix Guattari, Michel Foucault, and James Clifford literally intermingle with the images of current events and the works reproduced. This was the first time that these names had come together in association with works by artists. Many of the famous authors whose texts are included in the 600 pages of the book are those who, through their literary, political, and social commitment, marked the cultural movements of decolonization. The notion of 'becoming minority', created by Deleuze and Guattari, offers a major epistemological shift when it comes to decentralizing hegemonic positions. This was a time when the use of the Internet was not yet generalized and yet the way the concept of networks is established makes it possible to envisage encounters and interweaving. While Documenta $X$ confronted the political potential of art since 1945 with its existence in an ethnocentric Western world, it also helped to anticipate the artistic direction of Documental1, which was structured around the notion of democracy. Interestingly, the final interviews that conclude DocumentaX's book catalogue (David and Chevrier 1997) are those with Étienne Balibar and Jacques Rancière, two philosophers who reflected, in a distinct way, on the contemporary definition of democracy (Balibar et al. 1997; Rancière et al. 1997).

It is this notion of democracy based on the postcolonial question that serves as the springboard for the first platform entitled Democracy Unrealized, initiated by Enwezor and his co-curators. Enwezor, in an article published in 2003 entitled 'Postcolonial Constellation: Contemporary Art as a State of Permanent Transition', insisted on the importance of postcolonialism in his critical method as a curator:

Contemporary art today is refracted, not just from the specific site of culture and history but in a more critical sense, from the standpoint of a complex geopolitical configuration that defines all systems of production and relations of exchange as a consequence of globalization after imperialism. It is this geopolitical configuration and its postimperial transformations that situate what I call here 'the postcolonial constellation'. The changes wrought by transitions to new forms of governmentality and 
institutions, new domains of living and belonging as people and citizens, cultures, and communities, define the postcolonial matrix that shapes the ethics of subjectivity and creativity today.

(Enwezor 2003, 58)

Democracy Unrealized was held in Vienna on 15 March 2001 (while it was still possible to visit The Short Century in Munich). Discussions and conclusions continued in Berlin on 9 October 2001, a few days after the terrorist attacks of 11 September 2001, which led to the implementation of repressive policies on a global scale, while the symbolic hope of a renewal with the passage to the twenty-first century was brutally buried. This transformed landscape was no longer only that of art in a postcolonial perspective, but also, and even more importantly, that of historical links revisited in light of the power relationships between the different powers of the globe whose balances were reversed. This platform evoked, on the one hand, a construction of democracy that would be based, among other things, on the origins of the word (Rancière), or on the possibility of thinking of the notion of citizenship as intrinsic to class struggle and freedom (Balibar). On the other hand, there would be a frontal analysis of the process of democratization as totally inherent to global capitalism and how it would determine 'every facet of cultural and political life around the world' (Enwezor et al. 2002a, 13). It is precisely this issue of a pluriversal world view that was raised in the introduction to the publication of the first platform. In trying to define the term 'unrealized', which is attached to that of democracy in the title, the authors stress the imperative of discussing the way in which liberal democracy, in the wake of the Cold War, was presented not only as the best of all systems, but also as the most accomplished and the most complete. The co-curators analysed their project as follows:

The central impetus of this project is to discuss how liberal democracy has been presented in the post-Cold War setting - not only as the best system but as a totally realized, essentially completed project. From this rather triumphal, post-Cold War perspective, if democracy is to be described as a finished project, it means that no structural changes are conceivable or necessary, that it is complete in all its foundational features - only small technical adjustments and minor tinkering may be needed in future. The logic of this argument can be seen as the technocratic interpretation of the term unrealized, which is seen as fine tuning of democracy procedural methods and due processes that have already been largely settled. This has been the way in which the main Western democracies view themselves - at best, as 'incomplete implementations' of equality and justice on which modern democracy is based, rather than limits, flaws, dead-ends, and problematics inscribed in the principles themselves. In reaction to this presumption, we start from the idea that 
Democracy Unrealized is a matter of bringing to light what liberal democracy promises but fails to deliver.

(Enwezor et al. 2002a, 14-15)

It was in accordance with a real political commitment that the event was envisaged; it was not only a question of making the exhibition an artistic encounter, but of considering it in light of radical motivations that study the political, historical, social, and cultural stakes with precision. At the heart of these questionings in relation to democracy are the tools provided by postcolonialism, this 'emergence of the postcolonial state as it grapples with the imperfect legacy of imperialism and colonialism' (Enwezor et al. 2002a, 13). This impasse in democracy as conceived by the West is also underlined by Stuart Hall's essay 'Democracy, Globalization, and Difference', which opens the discussion to a plural approach, to the notion of democracy from which emerges, almost in spite of itself, the discourse on otherness and difference.

Hall begins his essay with an amusing reminder,

One is tempted to say of democracy what, according to an essay by Immanuel Wallerstein, Mahatma Gandhi said of Western Civilization. 'What do you think of Western Civilization, Mr Gandhi?' someone asked him. To which he replied, 'It would be a good idea'. The organizers of Documental 1 were wise to recognize that, in relation to the conditions of existence of artistic practice today, few topics are more significant than the fate and future of democracy.

(Hall 2002, 22)

Within the desire for a uniform and globalizing construction of the world, the flaws that appear to emanate, paradoxically, both from those who claim a nation-state and from those who manage to construct critical responses to this unilateral process of economic and cultural instrumentalization. At the very moment when the latter was imposing itself on the world at the end of the Second World War, this same world was unravelling in the wars of independence and decolonization. It is therefore within the context of major political disturbances and transformations, whose painful consequences are often minimized, that the notion of democracy tries to exist in a sometimes fallacious way. The decision to make democracy the subject of the first platform shed new light on the links that could be established between politics and art. The debates raised were also arranged with regard to contemporary artistic production. Students and professors (artists, theoreticians, art historians) of the Wien Akademie of Bildenden Kunst (Vienna Academy of Fine Arts) were also involved in these debates. It should also be remembered that the Democracy Unrealized platform was set in the Viennese context of Jörg Haider's Austria and that these exacerbated nationalisms are still visible in a number of European countries today. 
The second platform entitled Experiments with Truth: Transitional Justice and the Processes of Truth and Reconciliation was held in New Delhi, based on notions that examine the plural experience of truth. The third platform Créolité and Creolization took place in January 2002 in the Caribbean, on the island of Saint Lucia; Stuart Hall participated, along with Derek Walcott, the great Caribbean writer whose birthplace is Saint Lucia. Isaac Julien, born in 1960 in London, whose family is also from Saint Lucia, was present as well (Enwezor et al. 2002b).

Held in March 2002, the fourth platform, Under Siege: Four African Cities, which was organized in Lagos, questioned the future of large African cities, such as Freetown, Johannesburg, Kinshasa, or Lagos. It was thus in his country of origin that Okwui Enwezor completed an unprecedented theoretical journey. The idea of these platforms was indeed to make a reverse movement: if we consider the context in which all these postcolonial theories were developed, we see that they emanated from intellectuals from non-Western countries who came to Europe or the United States and began to teach and publish there. The importance of travelling to an island in the Caribbean, or going to a city in India or Nigeria to discuss directly on site with thinkers and others interested in the debate, was a novel process that served as a backward reminder of migration movements and key elements of colonial history. As Enwezor constantly reminds us, it is necessary to shift our gaze away from thinking that the centre and the periphery, the North and the South, are constituted solely from the West.

These are all questions that the fifth and final platform of Documentall was attempting to address in the form of an exhibition held in Kassel at five different locations in the city. The experience of the platforms was thus supposed to build a preliminary groundwork for an art event that would welcome around a hundred artists from all over the world and open up an international art space for the first time to 'others', that is, to those from other hemispheres of the globe. The theoretical requirements attached to the form 'exhibition' raise a question: while Documentall is a set of critical questions that lead to an exhibition, does a visit to the exhibition in Kassel provide an opportunity to question the themes addressed in the previous platforms? Does Platform 5, which is the exhibition, open up, thanks to the works, avenues for reflection that resonate with Platforms 1, 2, 3, and 4? In short, does the exhibition, which is in a way the culmination of this process put in place by the curators, allow us to understand, without referring to the discussions that have been held elsewhere in the world, what led to the choice of artists, the works, the locations, the scenography of the exhibition, the different buildings that housed the artistic works and the formal and theoretical correlations among them? Did all the conclusions of the discussions lead to a different way of thinking about the structure of an event like Documenta? What concessions were made? How were the notions of space-time thought out? These are the questions that might recur in every study of such largescale events. While the notion of mobility tends to be emphasized, the 

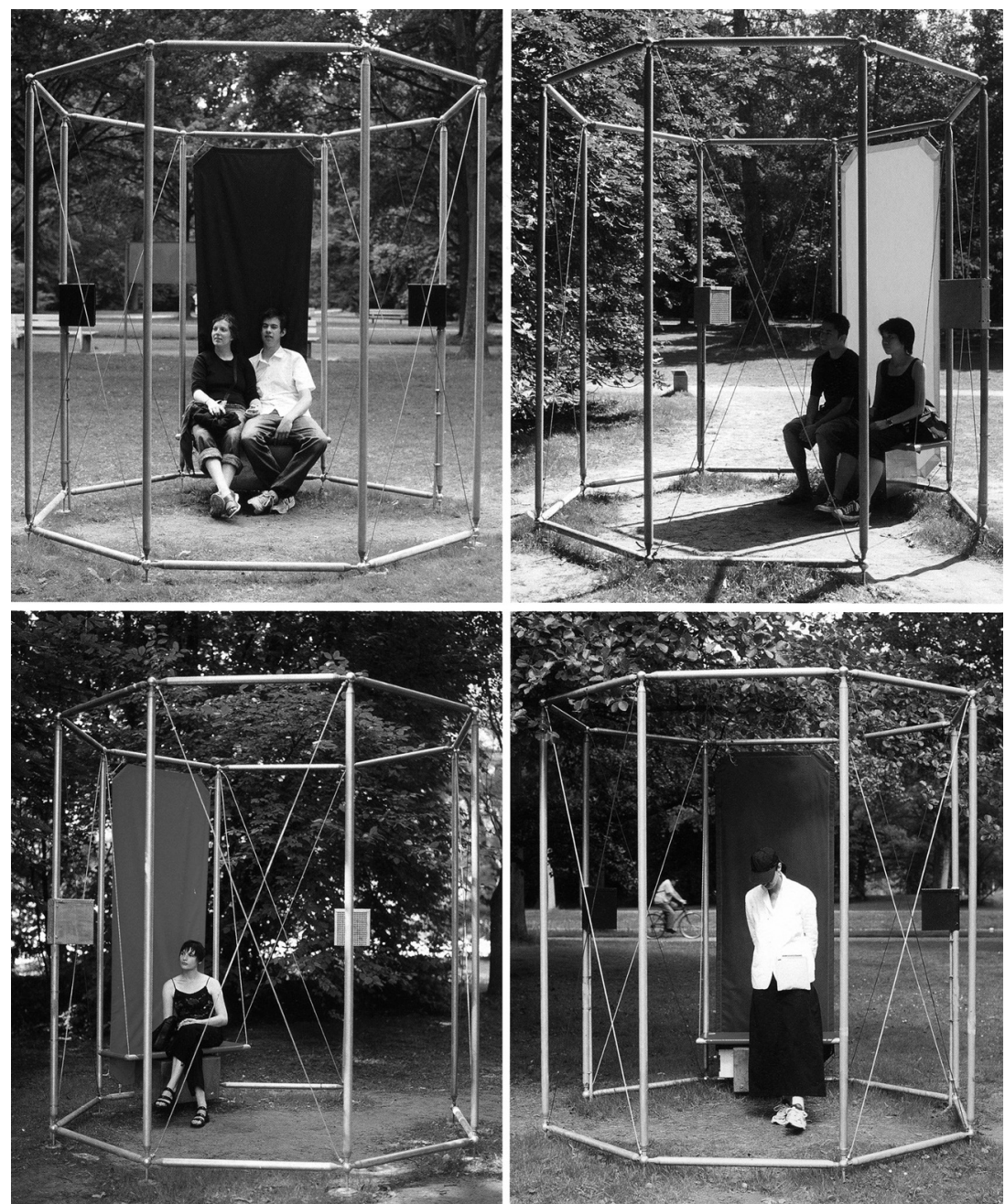

Figure 8.I Renée Green, Standardized Octogonal Units for Imagined and Existing Systems, 2002, Documenta II, Auepark, Kassel, 2002.

coexistence of proposals, whether they are plastic or filmic, whether they take the form of performance, installation or more traditional hanging, is a spatial parameter of existence. The curators of Documental1 selected 109 artists or collectives, a large majority of whom were from non-Western countries or were of non-Western origin but living in the Western world. It is through the pluriversality of perspectives and with these artists that contemporary political thought has been formed. 


\section{Terrible nearness of distant places}

A guiding thread in Okwui Enwezor's thinking as an intellectual, poet, and curator is the way places, near, and far, are entangled with each other. These near and far places are characterized by the concrete effects of displacement related to desired or forced migration, exile, colonization, the way colonial empires continue to exercise forms of economic, political, or symbolic power over former colonized countries. From the introduction he wrote for the Documental1 catalogue (and perhaps even before, but it has not been possible to verify this), Enwezor proposed reflecting on the question 'What is an avant-garde today? The postcolonial aftermath of globalization and the terrible nearness of distant places' (Enwezor 2002, 44). In 2007, the same idea was taken up in the concept he proposed for the second Seville Biennial of Contemporary Art (BIACS 2) entitled The Unhomely: Phantom Scenes in Global Society. In its introduction, he says:

BIACS 2 is thus conceived as an opportunity to address the contradictory logic of distance and proximity that represents the dialectical structure of many artistic procedures of the last decade, by highlighting the participation and engagement of contemporary artists in the deep interrogation of the fundamental historical realignments currently being generated through many forms and activities across the world...The exhibition will examine the ways in which artistic practice seeks to mediate the distinctions between civil society, civic space, and social reciprocity through community and collective activities.

(Enwezor 2007, 14)

The BIACS 2 project was conceived according to three 'framing points': the first point concerns the way intimacy is conceived in terms of representation and space, the second point elaborates the notion of proximity juxtaposed to that of contiguity. However, as Enwezor points out, "proximity here is not a form of shallow distance, rather it has increasingly become a form of disturbing nearness' (Enwezor 2007, 16). By comparing 'proximity' and 'nearness', two words with the same meaning, Enwezor seeks to differentiate between them by the very spatiality that brings them together, both objectively and subjectively. By evoking intimacy, he also opens up reflection to emotions. Finally, the third point takes into account the first two in order to question the concept of neighbourliness. The exhibition unfolded in the city, and a work such as the banner created by the American artist Renée Green made it possible to synthesize these three points where distance, strangeness, and proximity coexist and repel each other at the same time. On this banner, hung on the balcony of a building in the city, the word 'Bonvenon!' was displayed in large red letters on a blue background. This word of an unknown language is familiar but also foreign. Bonvenon means 'welcome' in the universal language Esperanto. By saying 'welcome' in Esperanto, this language without 
territory, Renée Green calls out to passers-by in the context of an exhibition whose curator insists on this 'terrible nearness of distant places'. Esperanto represents the utopia of a universal language that is nonetheless foreign to everyone (Figure 8.2).

Okwui Enwezor's 2012 exhibition in Paris confirms this leitmotiv with the way he has created vital connections between near and far. The Triennial held at the Palais de Tokyo is entitled Intense Proximity. In the concept paper written in April 2011, one year before the opening of the artistic event, Enwezor brings together the contextual and conceptual approaches behind his vision for la Triennale. By inviting the idea of inhabiting, which becomes a way of thinking about the space one occupies, the distance that separates us from others, the displacement that affects us when existing in a situation in which we are striving to belong, adhering or not to the structures that govern our position as a citizen. The 'measures of home' to which Enwezor refers resemble what he first names in all caps, 'THE BORDERS of France'. 'THE BORDERS,' he writes in his statement, 'are the parts of the territory that present a duality of near and far' (Enwezor 2011). This 'near' and 'far' are joined in the project's title, Intense Proximity, and here one feels its tension. This is mostly due to the fact that it springs from an anecdote, mentioned in the opening paragraph of Enwezor's piece, about that relatively evil incident of soup containing meat and pork that was distributed by extreme right-wing organizations to the homeless in 2006, and thereby discriminated against certain religions. Intensity could thus also be 'intrusion'. But the 'BORDERS'

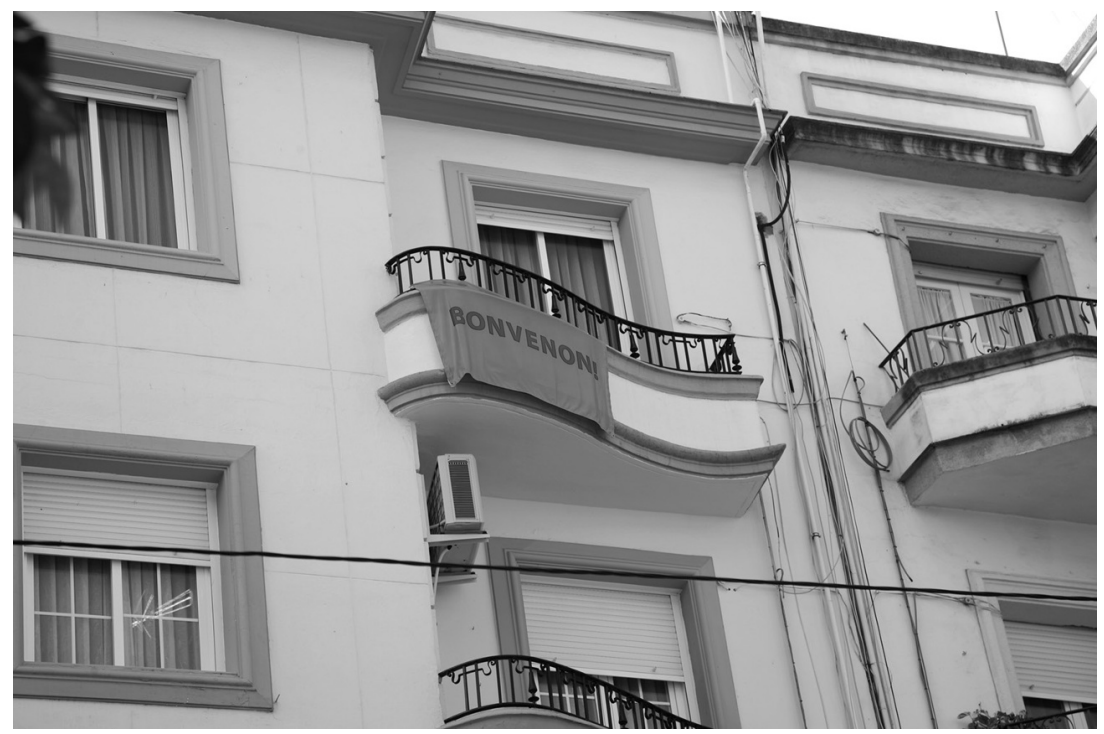

Figure 8.2 Renée Green, Bonvenon!, banner from Climates and Paradoxes, 2005. 


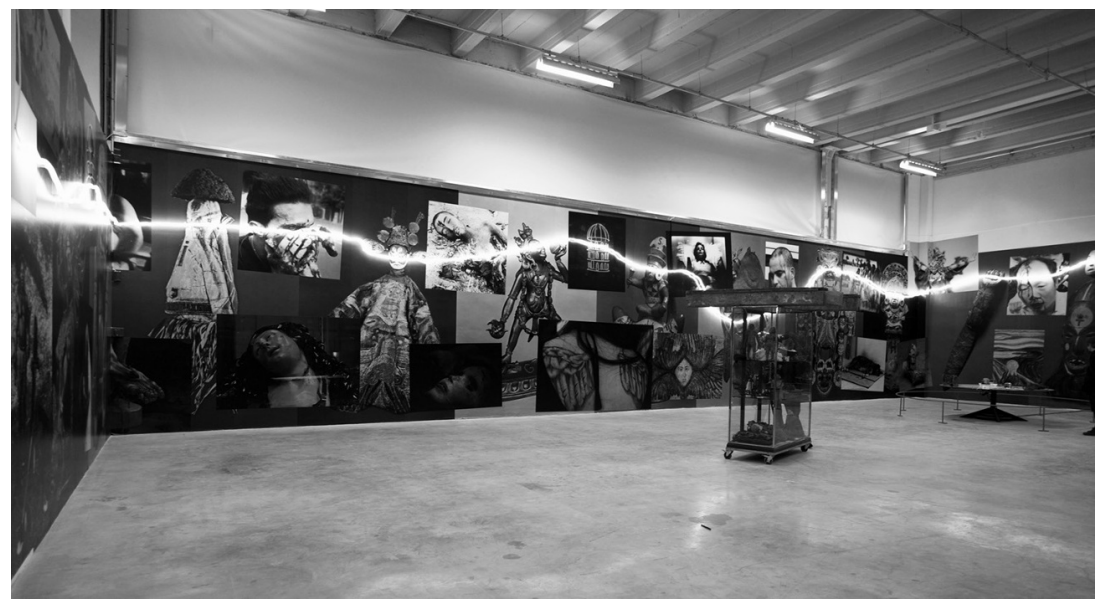

Figure 8.3 Sarkis, La frise des trésors de guerres (The frieze of war treasures), 2012, in Intense Proximity, Triennale, Paris, 2012.

of France are also responsible for its emphasis on cultural movement, shown in the way it values the idea of a 'frontier space' more than a 'national space'. Consider the country, France, where La Triennale takes place. It is a 'national space' that has broadened or expanded over thousands of kilometres and now touches three oceans-Atlantic, Pacific, and Indian. The movement of this 'national space' in terms of 'a physical place' as opposed to a 'frontier space' that acquires 'new contaminated morphologies (local, national, geographical, non-national) constantly' (Enwezor 2011) can be brought to mind perhaps, using this very astute explanation, and considering the specific case of the French Caribbean Islands (Les Antilles françaises). In reality, with France's overseas states (Martinique and Guadeloupe are nearly 7,000 kilometres from France) one can say that the 'national space' and the 'frontier space' are interchangeable, one and the same. While being completely beyond the border (hors frontière) geographically, they are connected politically, socially, and economically by an ongoing colonial history. However, its distinction is evident in a cultural perspective. It is the Creole language that weaves and preserves the links to memory, the history of slavery, the traces of violence and oppression, the poetry, the spoken and written word, the genealogy, the postcolonial, and the Utopia (Zabunyan 2012a, 2012b).

In the introduction to the anthology published on the occasion of the exhibition, Enwezor provides additional clarification:

The curatorial proposal of Intense Proximity begins with the assumption that the tensions that presently exist between social, cultural, economic, and political systems and their affiliated partisans is a common fact of contemporary multicultural societies. It also recognizes that parts of 
these complex communities and conversations are products of historical events in which processes of migration, colonialism, exile, and expulsion are intimately entangled.

(Enwezor 2012, 21)

When the 56th International Art Exhibition of the Biennale di Venezia opened in May 2015, all these processes listed by Okwui Enwezor were still relevant. That year was marked by the global media coverage of the tragedies related to the tens of thousands of deaths in the Mediterranean. Repeatedly and with an insistence that extended from exhibition to exhibition, Enwezor tirelessly reiterated that the world is forever wounded by these movements of people leaving their countries to try to find refuge in the inhospitable European countries that welcome them in often appalling conditions. In the catalogue, the artistic director of one of the oldest events of international contemporary art (the Venice Biennale was founded at the end of the nineteenth century, in 1895) recalled once again his reasons for making the exhibition a reflection of the world that humanity inhabits. His observation was bitter:

The global landscape is again in disarray. Today again it is scarred by violent turmoil, panicked by the shadow of economic crisis and viral pandemonium, secessionist politics, and a humanitarian catastrophe on the high seas, deserts, borderlands, as immigrants, refugees, and desperate people seek refuge in seemingly calmer, more prosperous lands. But recent news from elsewhere does suggest that there are no more safe havens... It seems, now, that we live in the terrible wakefulness of new crises, uncertainty, and a deepening insecurity across all regions of the world.

(Enwezor 2015, 18)

The period of profound turmoil he describes, recalling that in advance of this excerpt all the movements of political demands (civil rights movements, anticolonial projects, feminist struggles since the 1960s) and their impact on the work of artists, writers, filmmakers, composers, musicians, and actors are anchored irremediably to the present. By titling the biennial All the World's Futures, Enwezor shows that for him art and artists are at the heart of a historical process that links the past to the present, the present to the future, 'a project devoted to an appraisal of the relationship of art and artists to the current state of things' (Enwezor 2012, 19).

As a journal founder, curator, museum director and poet, Okwui Enwezor worked relentlessly from within the institutional system of art to transform the ways artistic productions are received from countries all over the worldcountries that, at some point in their history, have been confronted with colonization, exploitation, oppression, racism, discrimination. Deeply and elegantly linked to the artists with whom he built his path, he made his political and social commitment a successful gamble. By choosing to give artistic 
works in museums, biennials or major contemporary art events a critical and political function and by choosing to exhibit artists from all over the world under the same conditions as those imposed by the white cube of the museum, Okwui Enwezor changed the dominant canon and decolonized a history of exhibitions that, until the end of the 1990s, did not yet question the possible entanglements of memory, affects and colonial history. He participated in the creation of a reframed history of art by choosing a world historical perspective and insisting on the fact that European modernity was initiated by its contact with Africa.

An exhibition that he had conceived in 2018 and 2019, which he wanted to see open before the US presidential election of 2020 and was unable to finalize due to his illness before his passing, Grief and Grievance, Art and Mourning in America, was inaugurated in February 2021 at the New Museum in New York. A posthumous curatorial experience based on a grand narrative that resonates the most recent events in history with the violence of the past. Art history, as well as the history of exhibitions in the twenty-first century, began with Okwui Enwezor and continues with him, even in his absence.

\section{Notes}

1 "Postwar: Art Between the Pacific and the Atlantic, 1945-1965," Postwar at Haus der Kunst. Accessed 28 February 2021. https://postwar.hausderkunst.de/ en/.

2 In the follow on of the exhibition Post-war: Art Between the Pacific and the Atlantic, 1945-1965, Okwui Enwezor had thought of a second part for this postwar period, a major exhibition that he entitled Postcolonialism, which will be organized posthumously at the Sharjah Biennale in 2022, https://universes.art/ en/sharjah-biennial/2022.

3 Georges Adéagbo exhibited at The Short Century, at Documentall and the Paris Triennial; Frédéric Bruly Bouabré exhibited at The Short Century, at Documenta11; Isaac Julien exhibited at The Short Century, at Documental1, the Paris Triennial, the 56th Venice Biennale; Bodys Isek Kingelez exhibited at The Short Century, at Documenta1 1; Santu Mofokeng exhibited at The Short Century, at Documental1; Yinka Shonibare exhibited at The Short Century, at Documenta11; Pascale Marthine Tayou exhibited at The Short Century, at Documental1; Jane Alexander exhibited at The Short Century, at Documenta11; Renée Green exhibited at Documental1, at the 2nd Seville Biennale; Adrian Piper exhibited at Documenta11, the 2nd Seville Biennale, the Paris Triennial and the 56th Venice Biennale; Trinh T. Minh-ha exhibited at Documentall and the Paris Triennial; Steve McQueen exhibited at Documentall and the 2nd Seville Biennale; Harun Farocki exhibited at the 2nd Seville Biennale and the 56th Venice Biennale.

\section{References}

Allain-Bonilla, Marie-laure, Émilie Blanc, Johanna Renard, and Elvan Zabunyan. 2020. Constellations subjectives, pour une histoire féministe de l'art. DonnemarieDontilly: éditions iXe. 
Balibar, Étienne, Jean-François Chevrier, Catherine David, and Nadia Tazi. 1997. "Globalization/Civilisation 1" and "Globalization/Civilisation 2". In Politics/ Poetics, Documenta X, edited by Catherine David, 774-83; 786-99. Ostfildern-Ruit: Cantz.

Barcia, Manuel. 2009. "'Locking Horns with the Northern Empire': Anti-American Imperialism at the Tricontinental Conference of 1966 in Havana." Journal of Transatlantic Studies 7 (3): 208-17.

Becker, Carol, and Okwui Enwezor. 1998. "The Second Johannesburg Biennale.” Art Journal 57 (2): 86-107.

Becker, Carol, and Okwui Enwezor. 2002. "A Conversation with Okwui Enwezor." Art Journal 61 (2): 8-27.

Butler, Rex, and Okwui Enwezor. 2008. "Curating the World." Australian and New Zealand Journal of Art 9 (1-2): 14-21.

Chakrabarty, Dipesh. 2000. Provincializing Europe: Postcolonial Thoughts and Historical Difference. Princeton: Princeton University Press.

David, Catherine, and Jean-François Chevrier. 1997. Politics/Poetics, Documenta X. Ostfildern-Ruit: Cantz.

Dawson, Ashley. 2003. "The Short Century: Postcolonial Africa and the Politics of Representation." Radical History Review 87: 226-36.

De Sousa Santos. 2014. Epistemologies of the South: Justice against Epistemicide. Boulder: Paradigm Publishers.

El-Tayeb, Fatima. 2011. European Others: Queering Ethnicity in Postcolonial Europe. Minneapolis: University of Minnesota Press.

Enwezor, Okwui, ed. 2001. The Short Century: Independence and Liberation Movements in Africa 1945-1994. Munich: Prestel.

Enwezor, Okwui. 2002. "The Black Box.” In Documenta 11_Platform5: Exhibition, Ostfildern-Ruit: Hatje Cantz.

Enwezor, Okwui. 2003. "The Postcolonial Constellation: Contemporary Art in a State of Permanent Transition." Research in African Literatures 34 (4): 57-82.

Enwezor, Okwui. 2007. The Unhomely, Phantom Scenes in Global Society. Second International Seville Biennal of Contemporary Art, Seville: Fundacion Bienal Internacional de Arte Contemporaneo de Sevilla.

Enwezor, Okwui. 2011. Intense Proximité: l'art comme réseau, La Triennale, avantprojet. Palais de Tokyo: La Triennale. Unpublished manuscript. Microsoft Word file.

Enwezor, Okwui, ed. 2012. Intense Proximity: An Anthology of the Near and the Far. Paris: Artlys

Enwezor, Okwui, ed. 2015. "Introduction." In All the World's Futures, 56th Biennale di Venezia, edited by Okwui Enwezor Venice: Marsilio Editori.

Enwezor, Okwui. 2016. Lecture at Foundation Giacometti, 10 November 2016. https:// www.fondation-giacometti.fr/en/event/65/postwar-art-between-the-pacificand-the-atlantic-1945-1965.

Enwezor, Okwui, Carlos Basualdo, Ute Meta Bauer, Susanne Ghez, Sarat Maharaj, Mark Nash, and Octavia Zaya. 2002a. Democracy Unrealized, Documenta 11_ Platform 1. Ostfildern-Ruit: Hatje Cantz.

Enwezor, Okwui, Carlos Basualdo, Ute Meta Bauer, Susanne Ghez, Sarat Maharaj, Mark Nash, and Octavia Zaya. 2002b. Créolité and Creolization, Documenta 11_ Platform 3. Ostfildern-Ruit: Hatje Cantz. 
Enwezor, Okwui, Katy Siegel, and Ulrich Wilmes. 2016. Postwar: Art between the Pacific and the Atlantic, 1945-1965. Munich: Prestel.

Friedel, Julia. 2018. "Exhibition Histories.” C\&, 26 February 2018, https://contemporaryand.com/magazines/the-short-century/.

Glissant, Édouard. 1997. Poetics of Relation (1990). Translated by Betsy Wing. Ann Arbor: University of Michigan Press.

Hall, Stuart. 2002. "Democracy, Globalization, and Difference." In Democracy Unrealized, Documenta 11_Platform 1, edited by Enwezor, Okwui, Carlos Basualdo, Ute Meta Bauer, Susanne Ghez, Sarat Maharaj, Mark Nash, and Octavia Zaya, 21-36. Ostfildern-Ruit: Hatje Cantz.

Hassan, Salah, and Iftikhar Dadi. 2001. Unpacking Europe, Towards a Critical Reading. Rotterdam: Museum Boijmans Van Beuningen.

Ifversen, Jan. 2018. "Interculturality." ECHOES: European Colonial Heritage Modalities in Entangled Cities. Accessed 28 February 2021. https://keywordsechoes. com/interculturality.

Knudsen, Britta Timm. 2018. "Reframing." ECHOES: European Colonial Heritage Modalities in Entangled Cities. Accessed 28 February 2021. https://keywordsechoes. com/reframing.

Mahler, Anne Garland. 2018. From the Tricontinental to the Global South: Race, Radicalism, and Transnational Solidarity. Durham: Duke University Press.

Rancière, Jacques, Jean-François Chevrier, and Sophie Wahnich. 1997. "The Political Form of Democracy." In Politics/Poetics, Documenta X, edited by Catherine David, 800-4. Ostfildern-Ruit: Cantz.

Sakai, Naoki. 2001. "Dislocations of the WEST and the Status of the Humanities." In Unpacking Europe: Towards a Critical Reading, edited by Salah Hassan and Iftikhar Dadi, 196-215. Rotterdam: Museum Boijmans Van Beuningen.

Zabunyan, Elvan. 2012a. "Out of Sight, Out of Mind." In Intense Proximity, An Anthology of the Near and the Far, 101-6, Paris: Artlys

Zabunyan, Elvan. 2012b. "Rencontres Distancées/Distant Encounters." Critique d'art 40 (Autumn): 52-65. 